\title{
CAD-CAM endodontic posts: literature review
}

\author{
Pinos endodônticos CAD-CAM: revisão da literatura \\ Postes de endodoncia CAD-CAM: revisión de la literatura
}

Received: 12/19/2020 | Reviewed: 12/23/2020 | Accept: 12/28/2020 | Published: 01/02/2021

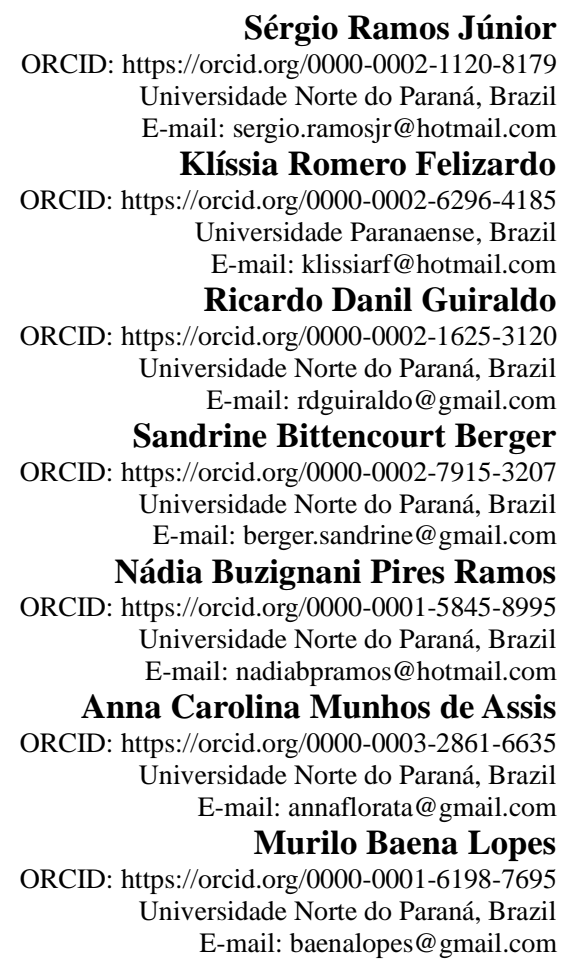

\begin{abstract}
In the actual times, with so many rehabilitation techniques and endodontic posts in the market, there are many doubts about which one is the best, the most cost-effective, the one that has more resistance among other questions. This work aimed to compare the intraradicular restorative treatments that involve the use of prefabricated posts and posts made with CAD-CAM, through a literature review in order to reinforce these procedures. Articles and other literary sources with interrelation to CAD-CAM and endodontic posts were surveyed through search in Pubmed, Scielo, Scopus, Lilacs and Google Scholar databases. The keywords: endodontic posts, CAD-CAM, prefabricated posts, customizable posts, fiberglass, carbon fiber were used. More than 100 articles were found, and after reading the abstract, 50 were selected. After reading, 26 were selected for the review. After reading, analyzing and interpreting the scientific studies, it was possible to verify that the CAD-CAM endodontic posts have satisfactory results, although there are few specific studies on them compared with the metallic cast posts and prefabricated posts.
\end{abstract}

Keywords: Permanent dental destoration; Computer-aided design; Endodontics.

\section{Resumo}

$\mathrm{Na}$ atualidade, com tantas técnicas de reabilitação e pinos endodônticos existentes no mercado, muitas são as dúvidas sobre qual é a melhor, a mais econômica, a que tem mais resistência entre outras questões. Este trabalho teve como objetivo comparar os tratamentos restauradores intra-radiculares que envolvem a utilização de pinos pré-fabricados e pinos confeccionados em CAD-CAM, por meio de uma revisão da literatura com o objetivo de reforçar esses procedimentos. Artigos e outras fontes literárias com inter-relação com CAD-CAM e postagens endodônticas foram levantados por meio de busca nas bases de dados Pubmed, Scielo, Scopus, Lilacs e Google Scholar. Foram utilizadas as palavras-chave: pinos endodônticos, CAD-CAM, pinos pré-fabricados, pinos customizáveis, fibra de vidro, fibra de carbono. Mais de 100 artigos foram encontrados e, após a leitura do resumo, 50 foram selecionados. Após a leitura, 26 foram selecionados para a revisão. Após a leitura, análise e interpretação dos trabalhos científicos, foi possível verificar que os pinos endodônticos CAD-CAM apresentam resultados satisfatórios, embora existam poucos estudos específicos sobre eles comparados aos pinos fundidos metálicos e pinos pré-fabricados.

Palavras-chave: Restauração dentária permanente; Desenho assistido por computador; Endodontia. 


\begin{abstract}
Resumen
En los tiempos que corren, con tantas técnicas de rehabilitación y postes de endodoncia en el mercado, existen muchas dudas sobre cuál es la mejor, la más rentable, la que tiene más resistencia entre otras cuestiones. Este trabajo tuvo como objetivo comparar los tratamientos restauradores intrarradiculares que implican el uso de postes prefabricados y postes realizados con CAD-CAM, mediante una revisión de la literatura con el fin de reforzar estos procedimientos. Se encuestaron artículos y otras fuentes literarias con interrelación con CAD-CAM y postes de endodoncia mediante búsquedas en las bases de datos Pubmed, Scielo, Scopus, Lilacs y Google Scholar. Se utilizaron las palabras clave: postes de endodoncia, CAD-CAM, postes prefabricados, postes personalizables, fibra de vidrio, fibra de carbono. Se encontraron más de 100 artículos y, tras la lectura del resumen, se seleccionaron 50. Después de la lectura, se seleccionaron 26 para la revisión. Después de leer, analizar e interpretar los estudios científicos, se pudo constatar que los postes de endodoncia CAD-CAM tienen resultados satisfactorios, aunque existen pocos estudios específicos sobre ellos en comparación con los postes fundidos metálicos y los postes prefabricados.
\end{abstract}

Palabras clave: Restauración dental permanente; Diseño asistido por computadora; Endodoncia.

\title{
1. Introduction
}

For many years, the gold standard for endodontically treated teeth with extensive loss of dental structure has been the manufacture of metal-ceramic crowns or total crowns in pure ceramics, with or without endodontic post. Over the years, the importance of preserving dental tissue, together with the evolution of dental materials, has introduced new principles in tooth restoration, leading to a more conservative dentistry. The development of CAD-CAM (Computer-Aided Design - ComputerAided Manufacturing) technology has opened new horizons, both in the processing of materials and in the restoration of teeth, providing precision, esthetics and restorative procedures that consume less time (Tzimas et al., 2018).

Intraradicular dental posts are used in dentistry to create retention for the restoration (Allan \& Foreman, 1989). Some materials are used in the manufacture of intraradicular retainers, including chromium-cobalt and nickel-chromium for cast metal posts, titanium for the prefabricated metallic posts and carbon fiber and glass fibers (Allan \& Foreman, 1989).

The prefabricated posts have the disadvantage of presenting a large cementation line compared to the cast metal posts (Spazzin et al., 2009; Verissimo et al., 2014). In recent years, the anatomical post has been gaining popularity because it is a variation of the technique of the prefabricated post, where the post is modeled with composite resin. The anatomical post technique presents the advantages of the prefabricated fiberglass post without the disadvantage of the cementation line (Grandini et al., 2003).

With the advancement of technology and production methods, the CAD-CAM system has become of great use for dentistry nowadays. A higher accuracy can be found due to this process is all digital and has no operator interference (Pang et al., 2019). Compared to traditional treatments, the glass fiber CAD-CAM restoration significantly increased fracture resistance of enlarged root canals (Pang et al., 2019). CAD-CAM posts and posts made of high-density polymer have been shown better performance than prefabricated fiber posts (Eid et al., 2019), with this, it becomes interesting to verify the behavior of anatomical CAD-CAM posts and their advantages over conventional prefabricated post, through the literature review.

\section{Methodology}

This study is a literature review and a qualitative study (Pereira et al., 2018). Articles and other literary sources with interrelation to CAD-CAM and endodontic posts were surveyed through research in Pubmed, Scielo, Scopus, Lilacs and Google Scholar databases. The keywords: endodontic posts, CAD-CAM, prefabricated posts, customizable posts, fiberglass, carbon fiber were used to do the survey. More than 100 articles were found, and after reading the abstract, 50 were selected, 26 after reading selected for review. 


\section{Results and Discussion}

The intraradicular posts used in dentistry are structures that provide extra retention for restorations. It is a resource widely used by dentists and thus end up generating numerous attempts to improve the material and technique.

Intracanal pins are cylindrical or conical structures, traditionally made of metal fiber or fiber used in the root canal of endodontically treated teeth. They have been widely used in dentistry in cases where the remaining coronal structure of the teeth is not sufficient to provide adequate support to the restorative material. Cast metal posts and posts were the most used in indirect restorations for years (Maroli et al., 2017).

Teeth indicated for endodontics, or already present with compromised structure, or by large caries lesions, or restorations, structurally affected walls, and in cases of retreatments, are carriers of posts (Lopes \& Siequeira Júnior, 2015). These occurrences require the professional, caution and critical common sense in the treatment.

Intraradicular posts are recommended for endodontically treated teeth, with significant loss of coronary structure (greater than 50\%) and more important structures, such as marginal ridges and pulp chamber ceiling (Bramante, 2004). The loss of these structures causes an increase in physical forces (deflection) of the remaining cusps and coronary structures and may lead to tooth fracture. The posterior teeth are forced vertically, without the use of intra-radicular posts in adhesive restorations (Machado, 2017). However, when coronary loss is very extensive an indirect metal post should be indicated, to provide retention to prosthesis crowns (Cohen, 2017). On the other hand, in the anterior teeth the forces focus obliquely and horizontally. The intraradicular post dissipates forces along the coronary and root part, preventing fracture (Machado, 2017). In teeth responsible for the desocclusion guide such as canines, posts are recommended. Patients with parafunctional habits tend to make a lot of shear force which contributes to the indication of the post to dissipate stress (Bramante, 2004).

In modern endodontics, biological knowledge is required, with an understanding of the behavior of the organism in the face of the changes promoted by the treatment, as well as knowledge of physical principles, through the analysis of the mastication forces on the treated tooth (Cohen, 2017).

The first attempt to increase retention in teeth with large coronary loss was through the use of cast metal post. In the mid-1900s the technique of cast metal post was developed (Baratieri, 2010).

\section{Cast metal posts}

Although the cast metal post has a long history of success, they have limitations with the contraindication of use in lacerated canal, which compromise the insertion of the post in adequate depth. Enlarged canals that have little dentin in the root walls require the use of resin to reinforce the walls prior to the installation of the intra-canal post (Baratieri, 2010). With this, it was necessary to develop alternatives, which culminated in the development of prefabricated posts.

\section{Prefabricated Fiber Posts}

These systems can reduce the incidence of root fractures compared to conventional prefabricated metallic or metallic posts. Fiber systems are cemented with adhesive systems, preferably dual or chemically activated adhesives. Its advantage is to present modulus of elasticity similar to dentin, thus, there is a lower concentration of masticatory forces in the dental apex, differing from the metallic posts, which can generate areas of stress concentration, which can lead to cracks and fractures in the dental structure (Baratieri, 2010). They also require a preparation with less root wear, resulting in greater root remnant (Baratieri, 2010). Endodontically treated teeth and restored with this type of post present a more favorable pattern of fracture, when it occurs, because the concentration of stresses are distributed near to the cervical region and the fracture usually occurs in the post instead of occurring at the root, which is common for the cast metal posts. However, fiber posts are more 
susceptible to the technique, requiring greater knowledge and preparation from the dentist, especially with regard to the process of cementation and coronary reconstruction.

The glass fibers posts have in their composition, silica, calcium, boron, sodium and aluminum base, along with polyethylene fibers, making them closer to the color of teeth and being considered the most esthetic posts when compared with carbon fiber, quartz, zirconia or metallic posts (Scotti \& Ferrrari, 2003).

Many endodontically treated teeth present greater loss of dental structure due to previous restorations, invasive carious lesions or removal of the dental structure due to endodontic access. Fiberglass posts were universally accepted as a method of promoting greater resistance when restoring an endodontically treated tooth. However, obtaining effective support to root canal walls is a challenge, considering the geometry and unfavorable limitations inherent to the physical-chemical properties of adhesive material. Despite the clinical success, concerns were raised about the effective capacity of these resinbased materials to attach the fiber posts to the root dentin, due to the unfavorable C-factor of the post space(Maroli et al., 2017). During the filling phase, the intimate contact of resin materials with the dentin of the root canal should ideally result in an excellent chemical-mechanical bond. Concerns were raised about the effective capacity of these resin-based materials to join the fiber rods to the root dentin, due to the unfavorable C-factor (Pupo et al., 2017). During the luting phase, intimate contact of resin materials with root canal dentin should ideally result in an excellent chemical-mechanical bond. The prefabricated posts have as a disadvantage the thicker cementing line, with this emerged the technique of anatomical posts.

\section{Anatomical prefabricated posts}

Elements with highly affected canal-crown treatment with high level of destruction have been the target of a large number of procedures in the dental region of dentistry. Thus, it will be necessary the need for intraradicular retainers to increase the stability and retention of rehabilitation the existing dental structures (Mumcu et al., 2010; Torabi \& Fattahi, 2009).

The anatomical post technique is suggested for the rehabilitation of anterior teeth with a largely destroyed canal and with a considerable portion of affected dentinal tissue. In this technique, in addition to the fiberglass post, composite resin is used to fill the flue in order to minimize the gap that would be completed by resin cement. Thus, the mixture of two materials (composite resin and post) will be useful and will have biomechanical behavior as a repositor of the missing dentin structure (Martins et al., 2011). The anatomical posts have a great success in fragile root treatments because they react in both aesthetics and masticatory function (Hattori et al., 2010). The fiber posts have a more uniform force distribution (tension) in the occlusal and root region compared to the metallic posts (Hattori et al., 2010).

The loss of much of the dental crown implies, in most cases, an indirect restorative treatment (crown). In such cases, there is usually a need for a root anchorage, which can be done by placing a prefabricated or customized post. In extreme fragile roots it is recommended to place a custom post or post. In the literature, it has been recommended the placement of a cast metal post for these situations. However, despite having a high resistance, this metal post, due to its high stiffness, can lead to an irreversible fracture of the root, with consequent loss of the dental element. The placement of a material with a modulus of elasticity (stiffness) similar to that of root dentin seems to reduce this problem. The anatomical post is a new alternative of customized posts for these cases of fragile roots, where an esthetic fiberglass post is placed, externally filled with direct composite resin, obtaining a perfect adaptation.

\section{CAD-CAM posts}

Advances in computer-aided design (CAD)/ computer-aided manufacturing (CAM) technologies and ease of application have allowed the development of new treatment concepts for modern dentistry (Spitznagel et al., 2018). CAD/CAM applications offer a standardized manufacturing process, resulting in a reliable, predictable and cost-effective 
workflow for individual and complex tooth-supported restorations (Spitznagel et al., 2018). CAD/CAM technology has advantages, including fingerprints and digital models, and the use of virtual articulators. However, the implementation of this technology is still considered expensive and requires highly trained personnel (Alghazzawi, 2016). Currently, design software has more applications. The precision of the restoration manufacturing can be better achieved with 5 -axis milling units (Alghazzawi, 2016).

Computer-aided design and manufacturing technology (CAD-CAM) simplified the planning and manufacturing procedures involved in partial roofing restorations and also led to the development of new materials with homogeneous structures that suffer less contraction when polymerized (Miyazaki \& Hotta, 2011; Steinmassl et al., 2017). The development of hybrid andmetal-free materials, combining two main restoration components (resin and ceramic), provided a wide range of materials with visual indications and improved biomechanical properties (Garcia-Engra et al., 2020).

Digital dentistry has been developed to increase workflow precision and to accelerate the production process (Lee et al., 2014; Mangano et al., 2017; Mangano et al., 2016); generally, use of CAD-CAM to realize customized posts generally was limited to scanning plaster models obtained from traditional impressions (Chen et al., 2014; Lee et al., 2014; Liu et al., 2010). Other authors purposed a different digital workflow in which a traditional silicon impression is scanned to mill a personalized CAD-CAM post and core (Falcao Spina et al., 2018). Studies show that both impressions and stone replicas can be digitized with a high reliability (Persson et al., 2009). Direct acquisition was considered quicker, more accurate and less invasive than indirect methods (Galhano et al., 2012; Guth et al., 2013), however an accurate intraoral scanning requires the skill, experience and knowledge of the operator, which might affect the outcome due to patient-related factors such as intraoral humidity, tongue movement and saliva flow.

CAD-CAM-fabricated posts combine the advantages of traditional custom posts and prefabricated fiber posts (Tong et al., 2020). The use of CAD-CAM fabricated post and core restorations has been suggested, and CAD/CAM fabricated zirconia post and core have been investigated (Awad \& Marghalani, 2007; Lee et al., 2014; Marghalani et al., 2012; Ozkurt et al., 2010). However, it is nearly impossible to retrieve zirconia post if fracture occurs, which leads to an irreversible tooth failure (Ozkurt et al., 2010).

Recent resin-based, computer-aided and computer-aided manufacturing (CAD-CAM), have been used to restore endodontically treated teeth (Tsintsadze et al., 2018). Adaptation of the restoration is important for clinical success (El Ghoul et al., 2020). The precision of the CAD-CAM post and core restoration allows for a minimal amount of cementing composite resin and can result in a better adhesion to the dentinal walls (Pinto et al., 2017). The post made with this system has precise adjustment in the canal, showed high esthetic and can be used in cases where there is no coronal remaining, besides being able to support extensive prostheses. The main advantage of the CAD-CAM technique, when compared to the traditional method, is the speed of preparation of the restoration, however more clinical studies are necessary to evaluate whether this method could make crowns satisfactory enough to resist for long periods (Batson et al., 2014; Sequeira-Byron et al., 2015).

\section{Conclusion}

After reading, analyzing and interpreting the scientific studies surveyed, it was possible to verify that the CAD-CAM endodontic posts have shown satisfactory results, although there are few specific studies, and there is a need to laboratorial and clinical studies using these technologies, such as three points bending test, clinical longevity and shear bond strength.

\section{References}

Alghazzawi, T. F. (2016, Apr). Advancements in CAD/CAM technology: Options for practical implementation. J Prosthodont Res, 60(2), 72-84. https://doi.org/10.1016/j.jpor.2016.01.003 
Allan, D. N., \& Foreman, P. C. (1989). Coroas e próteses parciais fixas: um manual ilustrado. Ed. Santos.

Awad, M. A., \& Marghalani, T. Y. (2007, Aug). Fabrication of a custom-made ceramic post and core using CAD-CAM technology. J Prosthet Dent, 98(2), 161-162. https://doi.org/10.1016/S0022-3913(07)60050-X

Baratieri, L. N. (2010). Odontologia Restauradora - Fundamentos \& Técnicas: Fundamentos e Técnicas (1a. ed. ed.). Ed. Santos.

Batson, E. R., Cooper, L. F., Duqum, I., \& Mendonca, G. (2014, Oct). Clinical outcomes of three different crown systems with CAD/CAM technology. J Prosthet Dent, 112(4), 770-777. https://doi.org/10.1016/j.prosdent.2014.05.002

Bramante, C. M. (2004). Acidentes e complicações no tratamento endodôntico. Santos.

Chen, Z., Li, Y., Deng, X., \& Wang, X. (2014, Jun). A novel computer-aided method to fabricate a custom one-piece glass fiber dowel-and-core based on digitized impression and crown preparation data. J Prosthodont, 23(4), 276-283. https://doi.org/10.1111/jopr.12102 .

Cohen, H. (2017). Caminhos da Polpa (11a. ed. ed.). Elsevier.

Eid, R., Juloski, J., Ounsi, H., Silwaidi, M., Ferrari, M., \& Salameh, Z. (2019, Jan 1). Fracture Resistance and Failure Pattern of Endodontically Treated Teeth Restored with Computer-aided Design/ Computer-aided Manufacturing Post and Cores: A Pilot Study. J Contemp Dent Pract, 20(1), 56-63. https://www.ncbi.nlm.nih.gov/pubmed/31102396.

El Ghoul, W. A., Ozcan, M., Ounsi, H., Tohme, H., \& Salameh, Z. (2020, Jan). Effect of different CAD-CAM materials on the marginal and internal adaptation of endocrown restorations: An in vitro study. J Prosthet Dent, 123(1), 128-134. https://doi.org/10.1016/j.prosdent.2018.10.024 .

Falcao Spina, D. R., da Costa, R. G., Correr, G. M., \& Rached, R. N. (2018, Aug). Scanning of root canal impression for the fabrication of a resin CAD-CAMcustomized post-and-core. J Prosthet Dent, 120(2), 242-245. https://doi.org/10.1016/j.prosdent.2017.08.009.

Galhano, G. A., Pellizzer, E. P., \& Mazaro, J. V. (2012, Nov). Optical impression systems for CAD-CAM restorations. J Craniofac Surg, 23(6), e575-579. https://doi.org/10.1097/SCS.0b013e31826b8043.

Garcia-Engra, G., Fernandez-Estevan, L., Casas-Terron, J., Fons-Font, A., Castelo-Baz, P., Agustin-Panadero, R., \& Roman-Rodriguez, J. L. (2020, Mar 18). Fracture Resistance of New Metal-Free Materials Used for CAD-CAM Fabrication of Partial Posterior Restorations. Medicina (Kaunas), 56(3). https://doi.org/10.3390/medicina56030132 .

Grandini, S., Sapio, S., \& Simonetti, M. (2003, Fall). Use of anatomic post and core for reconstructing an endodontically treated tooth: a case report. J Adhes Dent, 5(3), 243-247. https://www.ncbi.nlm.nih.gov/pubmed/14621246.

Guth, J. F., Keul, C., Stimmelmayr, M., Beuer, F., \& Edelhoff, D. (2013, May). Accuracy of digital models obtained by direct and indirect data capturing. Clin Oral Investig, 17(4), 1201-1208. https://doi.org/10.1007/s00784-012-0795-0 .

Hattori, M., Takemoto, S., Yoshinari, M., Kawada, E., \& Oda, Y. (2010, Mar). Durability of fiber-post and resin core build-up systems. Dent Mater J, 29(2), 224-228. https://doi.org/10.4012/dmj.2009-113.

Lee, J. H., Sohn, D. S., \& Lee, C. H. (2014, Sep). Fabricating a fiber-reinforced post and zirconia core with CAD/CAM technology. J Prosthet Dent, 112(3), 683-685. https://doi.org/10.1016/j.prosdent.2014.01.015.

Liu, P., Deng, X. L., \& Wang, X. Z. (2010, Jun). Use of a CAD/CAM-fabricated glass fiber post and core to restore fractured anterior teeth: A clinical report. J Prosthet Dent, 103(6), 330-333. https://doi.org/10.1016/S0022-3913(10)60071-6.

Lopes, H. P., \& Siequeira Júnior, J. F. (2015). Endodontia: biologia e técnica (5 ed ed.). Guanabara Koogan.

Machado, M. E. L. (2017). Endodontia: Ciência e Tecnologia (3a. ed ed.). Ed. Santos.

Mangano, F., Gandolfi, A., Luongo, G., \& Logozzo, S. (2017, Dec 12). Intraoral scanners in dentistry: a review of the current literature. BMC Oral Health, 17(1), 149. https://doi.org/10.1186/s12903-017-0442-x.

Mangano, F. G., Veronesi, G., Hauschild, U., Mijiritsky, E., \& Mangano, C. (2016). Trueness and Precision of Four Intraoral Scanners in Oral Implantology: A Comparative in Vitro Study. PLoS One, 11(9), e0163107. https://doi.org/10.1371/journal.pone.0163107 .

Marghalani, T. Y., Hamed, M. T., Awad, M. A., Naguib, G. H., \& Elragi, A. F. (2012, Aug). Three-dimensional finite element analysis of custom-made ceramic dowel made using CAD/CAM technology. J Prosthodont, 21(6), 440-450. https://doi.org/10.1111/j.1532-849X.2012.00860.x .

Maroli, A., Hoelcher, K. A. L., Reginato, V. F., Spazzin, A. O., Caldas, R. A., \& Bacchi, A. (2017, Jul 1). Biomechanical behavior of teeth without remaining coronal structure restored with different post designs and materials. Mater Sci Eng C Mater Biol Appl, 76, 839-844. https://doi.org/10.1016/j.msec.2017.03.152

Martins, L. R. M., Sartini, L. A. M., Araújo, C. T. P., Barreto, B. C. F., Silva, G. R., \& Soares, C. J. (2011). Restauração com pinos intrarradiculares anatômicos em grandes destruições coronárias. Rev. Assoc. Paul. Cir. Dent, 65(1), 60-64.

Miyazaki, T., \& Hotta, Y. (2011, Jun). CAD/CAM systems available for the fabrication of crown and bridge restorations. Aust Dent J, 56 Suppl 1, 97-106. https://doi.org/10.1111/j.1834-7819.2010.01300.x .

Mumcu, E., Erdemir, U., \& Topcu, F. T. (2010, May). Comparison of micro push-out bond strengths of two fiber posts luted using simplified adhesive approaches. Dent Mater J, 29(3), 286-296. https://doi.org/10.4012/dmj.2009-089. 
Ozkurt, Z., Iseri, U., \& Kazazoglu, E. (2010, May). Zirconia ceramic post systems: a literature review and a case report. Dent Mater J, 29(3), 233-245. https://www.ncbi.nlm.nih.gov/pubmed/20467158 .

Pang, J., Feng, C., Zhu, X., Liu, B., Deng, T., Gao, Y., Li, Y., \& Ke, J. (2019, Feb 8). Fracture behaviors of maxillary central incisors with flared root canals restored with CAD/CAM integrated glass fiber post-and-core. Dent Mater J, 38(1), 114-119. https://doi.org/10.4012/dmj.2017-394.

Pereira, A. S., Shitsuka, D. M., Parreira, F. J., \& Shitsuka, R. (2018). Metodologia da pesquisa científica (1a. ed.). Universidade Federal de Santa Maria.

Persson, A. S., Oden, A., Andersson, M., \& Sandborgh-Englund, G. (2009, Jul). Digitization of simulated clinical dental impressions: virtual threedimensional analysis of exactness. Dent Mater, 25(7), 929-936. https://doi.org/10.1016/j.dental.2009.01.100.

Pinto, A., Arcuri, L., Carosi, P., Nardi, R., Libonati, A., Ottria, L., \& Campanella, V. (2017, Oct-Dec). In vitro evaluation of the post-space depth reading with an intraoral scanner (IOS) compared to a traditional silicon impression. Oral Implantol (Rome), 10(4), 360-368. https://doi.org/10.11138/orl/2017.10.4.360.

Pupo, Y. M., Casacqui, E., de Lima, P. A., Michel, M. D., Bueno, A. L., \& Michelotto, A. L. (2017, Jan-Feb). Morphology of root canal surface: A reflection on the process of cementation of the composite relined glass fiber post. Indian J Dent Res, 28(1), 59-65. https://doi.org/10.4103/ijdr.IJDR_189_16 .

Scotti, R., \& Ferrrari, M. (2003). Pinos de fibras considerações teóricas e aplicações clínicas. Ed. Artes Médicas.

Sequeira-Byron, P., Fedorowicz, Z., Carter, B., Nasser, M., \& Alrowaili, E. F. (2015, Sep 25). Single crowns versus conventional fillings for the restoration of root-filled teeth. Cochrane Database Syst Rev(9), CD009109. https://doi.org/10.1002/14651858.CD009109.pub3

Spazzin, A. O., Galafassi, D., de Meira-Junior, A. D., Braz, R., \& Garbin, C. A. (2009, Mar-Apr). Influence of post and resin cement on stress distribution of maxillary central incisors restored with direct resin composite. Oper Dent, 34(2), 223-229. https://doi.org/10.2341/08-73.

Spitznagel, F. A., Boldt, J., \& Gierthmuehlen, P. C. (2018, Sep). CAD/CAM Ceramic Restorative Materials for Natural Teeth. J Dent Res, 97(10), 1082-1091. https://doi.org/10.1177/0022034518779759.

Steinmassl, P. A., Klaunzer, F., Steinmassl, O., Dumfahrt, H., \& Grunert, I. (2017, Mar/Apr). Evaluation of Currently Available CAD/CAM Denture Systems. Int J Prosthodont, 30(2), 116-122. https://doi.org/10.11607/ijp.5031.

Tong, Z., Zhou, Y., \& Wei, X. (2020). A Severely Damaged Mandibular First Molar Restoration with CAD/CAM Customized Hybrid Ceramic Post and Core by Direct Intraoral Impression: A Case Report. Clin Case Rep, 10(10), 1-5. https://doi.org/10.37421/jccr.2020.10.1383 .

Torabi, K., \& Fattahi, F. (2009, Jul-Sep). Fracture resistance of endodontically treated teeth restored by different FRC posts: an in vitro study. Indian J Dent Res, 20(3), 282-287. https://doi.org/10.4103/0970-9290.57359.

Tsintsadze, N., Juloski, J., Carrabba, M., Goracci, C., Vichi, A., Grandini, S., \& Ferrari, M. (2018). Effects of scanning technique on in vitro performance of CAD/CAM-fabricated fiber posts. J Oral Sci, 60(2), 262-268. https://doi.org/10.2334/josnusd.17-0254.

Tzimas, K., Tsiafitsa, M., Gerasimou, P., \& Tsitrou, E. (2018, Nov). Endocrown restorations for extensively damaged posterior teeth: clinical performance of three cases. Restor Dent Endod, 43(4), e38. https://doi.org/10.5395/rde.2018.43.e38.

Verissimo, C., Simamoto Junior, P. C., Soares, C. J., Noritomi, P. Y., \& Santos-Filho, P. C. (2014, Mar). Effect of the crown, post, and remaining coronal dentin on the biomechanical behavior of endodontically treated maxillary central incisors. J Prosthet Dent, 111(3), 234-246. https://doi.org/10.1016/j.prosdent.2013.07.006. 